\title{
Abundance and Phosphorylation State of Translation Initiation Factors in Mammary Glands of Lactating and Nonlactating Dairy Cows
}

\author{
C. A. Toerien and J. P. Cant ${ }^{1}$ \\ Department of Animal and Poultry Science, University of Guelph, Ontario, N1G 2W1 Canada
}

\begin{abstract}
To test if control of mRNA translation is involved in the increase in protein synthesis by mammary glands during lactation, cellular contents and phosphorylation states of translation factors and their upstream regulators were measured in mammary parenchyma from 12 nonpregnant dairy cows. For a 42-d period, 6 cows in late lactation continued to be milked (L) and 6 at the same stage of lactation were dried off (NL). All cows were then slaughtered and mammary glands and tissue samples obtained. Alveoli and lobules tended to be larger in L cows. Mammary parenchymal mass, cell number, cell size, and RNA, DNA, and protein contents were greater in L cows. Increases (3.1- and 1.8-fold) in the abundance of active, phosphorylated ribosomal protein S6 and its kinase, S6K1, respectively, in L vs. NL parenchyma indicated an ability to sustain greater rates of synthesis of translational machinery, which was also evident in the $102 \%$ increase in parenchymal RNA:DNA between the 2 groups. Cellular abundances of the main eukaryotic translation initiation factors (eIF), eIF2 and eIF4E, were 2.6- and 3-fold greater, respectively, in $\mathrm{L}$ cows. That these differences were greater than the $102 \%$ greater RNA:DNA in L mammary parenchyma suggests an elevated translational efficiency in L glands. Abundance of phosphorylated rpS6 was not different between mammary parenchyma and liver, whereas eIF $2 \alpha$ was $50 \%$ greater in mammary tissue. In semimembranosus muscle, abundances of phosphorylated rpS6 and eIF2 $\alpha$ were 3 to 4 times lower than in mammary parenchyma. In both L and NL mammary glands, $11 \%$ of eIF $2 \alpha$ was in the inhibitory, phosphorylated form and 48 to $60 \%$ of eIF4E was complexed with its binding protein, 4EBP1. It is concluded that up-regulation of initiation of mRNA translation occurs in the fully differentiated milk secretory cell and that, where crucial initiation factors are not present in a
\end{abstract}

Received November 20, 2006.

Accepted February 26, 2007.

${ }^{1}$ Corresponding author: jcant@uoguelph.ca maximally active form, the initiation rate might be flexible in response to external stimuli.

Key words: involution, lactation, mammary gland, mRNA translation

\section{INTRODUCTION}

Terminal differentiation of mammary secretory cells at the onset of lactation is characterized by the expression of milk protein genes. The lactogenic hormones prolactin, insulin, and cortisol synergistically activate transcription through receptor-mediated signaling pathways that converge at the promoters of several milk protein genes (Rosen et al., 1999). Transcriptional regulation clearly plays a role in the increase in fractional protein synthesis rates from $29 \% / \mathrm{d}$ in mammary glands of dry, nonpregnant goats to $108 \% / d$ in lactating goats (Baracos et al., 1991). However, insulin and prolactin also up-regulate translation of milk protein mRNA in cultured mouse mammary epithelial cells during differentiation (Choi et al., 2004).

Acute regulation of protein synthesis in cells and tissues is controlled mainly at the point of translation initiation (Hershey, 1991) through phosphorylation of eukaryotic initiation factors (eIF) and associated proteins (Raught et al., 2001; Proud, 2005). This provides the organism with a rapid and reversible way to modulate protein synthesis in response to environmental stimuli such as consumption of a meal (Davis et al., 2000 ), change in amino acid concentrations (Kimball et al., 1991), and $\mathrm{Ca}^{2+}$ depletion (Kimball and Jefferson, 1992). The eIF bring the 2 ribosomal subunits, the mRNA and the initiator methionyl-tRNA, together as an initiation complex from which elongation of the peptide chain can proceed. The 2 most important factors for control of translation appear to be eIF2 and eIF4E (Raught et al., 2001; Proud, 2005). In addition, phosphorylation of ribosomal protein S6 (rpS6) is linked to an increase in the translation of parts of the translational machinery, including ribosomal proteins, eukaryotic elongation factors (eEF) $1 \mathrm{~A}$ and 2, and poly(A)binding proteins (Raught et al., 2001), so rpS6 plays a major role in modulating global rates of protein synthesis. 
The cellular content and phosphorylation state of eIF2, eIF4E, its binding protein 4EBP1, rpS6, and upstream regulators such as the rpS6 kinase (S6K1) and mammalian target of rapamycin (mTOR) have been demonstrated to be so universally up- or down-regulated in accord with the protein synthetic activity of tissues such as liver, muscle, and adipose as to be considered biomarkers of the process (Kimball et al., 2004). Expression of these biomarkers in mammary tissue has been studied very little. Prolactin increased the phosphorylation state of $4 \mathrm{EBP} 1$ in cultured mouse mammary epithelial cells pretreated with insulin (Choi et al., 2004). However, the stimulation of milk protein mRNA translation appeared to occur via lengthening of the poly(A) tail, specifically on milk protein mRNA (Choi et al., 2004), suggesting that mRNA is preferentially translated as opposed to degraded. Removal of all amino acids or only Leu from the culture media of bovine mammary epithelial cells caused a decrease in synthesis rate of the milk protein $\beta$-LG that was associated with dephosphorylation of 4EBP1 and S6K1 (Moshel et al., 2006). Furthermore, an inhibitor of the mTOR signaling pathway, by which amino acids are thought to activate protein synthesis (Nobukuni et al., 2005), significantly reduced the degree of reactivation of $\beta$-LG translation upon restoration of amino acid concentrations in the media (Moshel et al., 2006). From mammary tissue gathered in vivo, the level of eIF4E mRNA was 8 times greater in lactating cows than in postpubertal heifers (Long et al., 2001). No eIF4E mRNA was detected in mammary glands of prepubertal heifers (Long et al., 2001) and neither the abundance of eIF4E nor its distribution between biologically active and inactive forms were determined. To our knowledge, eIF2 has not been studied in mammary tissue. Christophersen et al. (2002) reported levels of eEF2 in the bovine mammary gland 20 and 50 times greater than those found in liver and skeletal muscle, respectively, and 2 times greater than in the mammary gland of a heifer.

Our hypothesis was that control of mRNA translation is involved in the increase in milk protein synthesis during lactation. According to this hypothesis, we predicted an increase in cell content or phosphorylation state of initiation factors and their associated regulators in secretory cells of the lactating mammary gland relative to nonlactating tissue. To test the hypothesis, we compared mammary content of major initiation factors and associated proteins between cows at the end of a normal lactation cycle and those at a similar stage but not lactating, in the absence of the confounding mammogenic and lactogenic effects of pregnancy.

\section{MATERIALS AND METHODS}

\section{Animals and Treatments}

All animal procedures were approved by the Animal Care Committee of the University of Guelph. Twelve multiparous cows were allocated randomly to 1 of 2 groups as they approached a daily milk yield of $\sim 15 \mathrm{~kg} /$ d. During the next $42 \mathrm{~d}$, the lactating group $(\mathbf{L}$; initial DIM $293 \pm 18 ; 17.4 \pm 0.7 \mathrm{~kg}$ milk/d) continued to be milked twice daily at 0500 and $1500 \mathrm{~h}$, whereas animals in the nonlactating group (NL; initial DIM $305 \pm 25$; $17.6 \pm 0.8 \mathrm{~kg} \mathrm{milk} / \mathrm{d}$ ) were dried off by abrupt cessation of milking. Cows in both treatments were housed in tie stalls with ad libitum access to hay (60\% timothy:40\% alfalfa). Lactating cows also received $1.43 \mathrm{~kg}$ (DM basis) of a concentrate containing $15.4 \% \mathrm{CP}$ and $1.58 \mathrm{Mcal}$ of $\mathrm{NE}_{\mathrm{L}} / \mathrm{kg}$ (Floradale Feed Mill Ltd., Ontario, Canada) following each milking. All cows were slaughtered at the end of their respective 42 -d periods.

\section{Blood and Tissue Collection}

Three to $4 \mathrm{~d}$ before slaughter, blood was collected from the jugular vein of each animal at approximately $1000,1300,1600$, and $1900 \mathrm{~h}$. Samples were kept on ice until centrifuged for $15 \mathrm{~min}$ at $10,000 \times \mathrm{g}$ and plasma was stored at $-20^{\circ} \mathrm{C}$.

Lactating cows were milked 1 to $2 \mathrm{~h}$ before slaughter. At slaughter, the animals were stunned with a captive bolt, exsanguinated, and the mammary glands were removed. Four samples of parenchymal tissue (5 to 10 $\mathrm{g}$ each) were removed from the center of the right rear quarter of the mammary gland 2 to $5 \mathrm{~cm}$ below the attachment to the ventral body wall. Samples were wrapped in double-layered aluminum foil envelopes and frozen in liquid $\mathrm{N}_{2}$. During collection, care was taken to avoid visible connective tissue. All samples were collected within 10 min of the start of exsanguination. Samples were double bagged and stored at $-70^{\circ} \mathrm{C}$. From 3 cows per group, 5 to $10 \mathrm{~g}$ of liver and semimembranosus muscle were also collected, processed, and stored in the same way as the mammary tissue samples.

\section{Mammary Gland Composition}

After sampling, mammary glands were weighed, double bagged, and stored at $-20^{\circ} \mathrm{C}$ until dissected into skin, parenchyma, adipose, connective tissue, and lymphatic fractions. Each fraction was weighed with corrections for the weight of samples harvested and fluid losses while dissecting.

\section{Plasma Analyses}

Plasma samples were pooled for each cow and analyzed spectrophotometrically for glucose by enzymelinked assay (kit no. 510-A; Sigma Chemical Co., Oakville, Ontario, Canada), $\alpha$-amino $\mathrm{N}$ by the method of Evans et al. (1993), and insulin by RIA (Medicorp, Montreal, Quebec, Canada). 


\section{Histology}

One to $2 \mathrm{~g}$ of mammary tissue from each sample that had been kept at $-70^{\circ} \mathrm{C}$ was thawed at room temperature overnight in $10 \%$ formalin in PBS and embedded in paraffin. Sections $(4 \mu \mathrm{m})$ were cut and stained with Martius yellow-scarlet-blue (Lendrum et al., 1962) to show connective tissue and fibrin, or hematoxylin and eosin (Prophet et al., 1992) to visualize nuclei. Number of lobules and the cross-sectional areas occupied by alveolar, connective, and adipose tissue were quantified by evaluating 9 random regions of interest (ROI) of the same dimensions for each animal, and captured as digital images at a magnification of $25 \times$, using Openlab 2.2.5 imaging software (Improvision Ltd., Lexington, MA). The number of alveoli was similarly quantified by evaluating 15 intralobular ROI per animal at a magnification of $400 \times$.

\section{Immunoblots}

Three to $6 \mathrm{~g}$ of frozen tissue from each cow was ground to a fine powder in liquid $\mathrm{N}_{2}$ using a mortar and pestle, and RNA, DNA, and protein were extracted in Tripure (Roche Diagnostics, Laval, Quebec, Canada) lysing buffer following the manufacturer's protocol. Nucleic acids were quantified spectrophotometrically at 260 and $280 \mathrm{~nm}$ and protein was measured by the BioRad detergent compatible assay (BioRad, Hercules, CA). Total mammary parenchymal RNA, DNA, and protein masses were calculated from the respective tissue concentrations and the amount of parenchymal tissue dissected.

Intracellular protein was harvested by homogenizing tissue in 5 volumes of ice-cold lysing buffer $(20 \mathrm{mM}$ Tris, pH 7.5, containing $150 \mathrm{~m} M \mathrm{NaCl}, 1 \mathrm{~m} M$ EDTA, $1 \mathrm{~m} M$ EGTA, $2.5 \mathrm{mM} \mathrm{Na}\left(\mathrm{HPO}_{4}\right)_{2}, 1 \mathrm{~m} M \beta$-glycerophosphate, $1 \mathrm{~m} M \mathrm{Na}_{3} \mathrm{VO}_{4}, 1 \%$ Triton X-100, $1 \mu \mathrm{g} / \mathrm{mL}$ leupeptin, and $1 \mathrm{~m} M$ phenylmethylsulfonyl fluoride) according to Bigot et al. (2003). The supernatant of a 15-min centrifugation at $15,000 \times g$ and $4^{\circ} \mathrm{C}$ was collected and protein content was measured as above. For each of the proteins investigated, a $40-\mu \mathrm{L}$ aliquot containing 1 to $2 \mu \mathrm{g} / \mu \mathrm{L}$ of protein was mixed with $10 \mu \mathrm{L}$ of $5 \times$ Laemmli SDS buffer containing $\beta$-mercaptoethanol and heated at $98^{\circ} \mathrm{C}$ for $3 \mathrm{~min}$. Samples were loaded onto polyacrylamide gels and subjected to electrophoresis at $100 \mathrm{~V}$. Molecular size was measured against a biotinylated protein ladder (10 to $200 \mathrm{kDa}$; Cell Signaling, Beverly, MA), and a visible molecular weight marker (Rainbow Molecular Weight Marker; Amersham, Piscataway, NJ) was used to track the movement of bands in a gel. Proteins in gels were electrotransferred overnight onto a polyvinylidene fluoride membrane (BioRad), which was blocked with 5\% (wt/vol) skim milk for $1 \mathrm{~h}$ at room temperature. Unless otherwise specified, membranes were incubated with primary rabbit anti-human antibody overnight at $4^{\circ} \mathrm{C}$, and with secondary antibody for $1 \mathrm{~h}$ at room temperature. Horseradish peroxidase linked to the secondary antibody was assayed by an enhanced chemiluminescence protocol (Cell Signaling). Band intensity was quantified using Northern Eclipse software (Version 6.0; Empix Imaging Inc., Mississauga, Ontario, Canada). Results were normalized to a DNA unit basis to express relative protein concentration per cell.

For total and phosphorylated eIF2 $\alpha$, proteins were separated on $12 \%$ gels and blotted with an antibody that recognizes eIF $2 \alpha$ only when phosphorylated on Ser $^{51}$ (Cell Signaling). Results were normalized for total eIF2 $\alpha$ (Anthony et al., 2001) with a rabbit anti-human polyclonal antibody that recognizes the protein irrespective of phosphorylation state (Santa Cruz Biotechnology, Inc., Santa Cruz, CA). Membranes were incubated with anti-eIF $2 \alpha$ for $1 \mathrm{~h}$ at room temperature.

For phosphorylated rpS6 and phosphorylated S6K1, proteins were separated on $10 \%$ gels and separately probed for rpS6 phosphorylated on $\mathrm{Ser}^{235 / 236}$ and S6K1 phosphorylated on $\mathrm{Thr}^{389}$ (Cell Signaling).

Unphosphorylated and phosphorylated eIF4E were detected, after separation on $12 \%$ gels, with a polyclonal anti-eIF4E IgG raised against a recombinant protein representing the full-length eIF4E of human origin (Santa Cruz Biotechnology, Inc.), and a polyclonal antibody against a synthetic phosphopeptide corresponding to residues surrounding Ser ${ }^{209}$ of human eIF4E (Cell Signaling). Free eIF4E and the 4EBP1·eIF4E and eIF4$\mathrm{G} \cdot \mathrm{eIF} 4 \mathrm{E}$ complexes were separated on $11 \%$ native gels and the membranes were probed for eIF4E using the same anti-eIF4E antibody as above.

\section{Statistical Analysis}

Least squares means were obtained by applying 1way ANOVA (Version 8, SAS Institute Inc., 2000), with the PDIFF option used to identify significant differences between treatments. The level of significance was set at $P \leq 0.05$ and trends were considered at $0.05<P$ $\leq 0.15$.

\section{RESULTS}

\section{Milk Production and BCS}

During the 42-d involution period, milk production of the L cows decreased from $17.4 \pm 0.7$ to $16.1 \pm 0.8$ $\mathrm{kg} / \mathrm{d}$. All cows were in a positive energy balance as judged by an increase in BCS. 
Table 1. Composition of mammary glands of nonpregnant lactating (L) and nonlactating (NL) dairy cows ( $\mathrm{n}=6$ /group) in late lactation

\begin{tabular}{|c|c|c|c|c|}
\hline \multirow[b]{2}{*}{ Component } & \multicolumn{2}{|c|}{ Group } & \multirow[b]{2}{*}{ SEM } & \multirow[b]{2}{*}{$P$-value } \\
\hline & $\mathrm{L}$ & NL & & \\
\hline Whole gland, kg & 22.6 & 16.0 & 2.3 & 0.07 \\
\hline Parenchyma, kg & 14.4 & 6.2 & 1.4 & 0.002 \\
\hline Connective, kg & 4.0 & 3.3 & 0.8 & 0.54 \\
\hline Adipose, kg & 1.7 & 4.0 & 0.6 & 0.03 \\
\hline Skin, kg & 2.2 & 2.2 & 0.4 & 0.92 \\
\hline Lymph, kg & 0.3 & 0.3 & 0.1 & 0.48 \\
\hline \multicolumn{5}{|c|}{ Fraction of whole udder weight } \\
\hline Parenchyma, \% & 63.6 & 37.6 & 3.2 & $<0.001$ \\
\hline Connective, \% & 16.9 & 20.5 & 2.2 & 0.27 \\
\hline Adipose, \% & 8.6 & 25.3 & 3.9 & 0.012 \\
\hline Skin, \% & 9.6 & 14.4 & 2.0 & 0.12 \\
\hline Lymph, \% & 1.3 & 2.2 & 0.4 & 0.1 \\
\hline
\end{tabular}

\section{Plasma Metabolites and Insulin}

Plasma concentration of $\alpha$-amino $\mathrm{N}$ was similar $(P=$ $0.31)$ in $\mathrm{L}$ and NL cows (1.62 \pm 0.34 vs. $2.06 \pm 0.39 \mathrm{mM})$. Plasma glucose concentration was lower $(P=0.002)$ in $\mathrm{L}(3.28 \pm 0.17 \mathrm{mM})$ than in NL $(3.78 \pm 0.11 \mathrm{mM})$ cows. Plasma insulin concentration was lower $(P=0.001)$ in $\mathrm{L}(0.31 \pm 0.01 \mathrm{ng} / \mathrm{mL})$ than in $\mathrm{NL}(0.57 \pm 0.03 \mathrm{ng} /$ $\mathrm{mL}$ ) cows.

\section{Composition of Mammary Glands}

Mammary glands tended to be larger in $\mathrm{L}$ than in NL cows (Table 1). When expressed as a percentage of the whole gland, the parenchymal fraction was significantly greater in the L cows (Table 1 ). Conversely, the extraparenchymal adipose fraction was greater in NL than in L cows.

\section{Effect of Lactation on Mammary Parenchyma}

Visually, the mammary glands of L cows showed an increase in lobule size compared with those of NL cows (Figure 1), and tended to have a greater proportion of the cross-sectional area per ROI comprised of alveoli $(P=0.13$; Figure 2$)$ and a lower lobular proportion $(P=$ 0.15 ; Figure 2). Similarly, the number of alveoli per ROI tended $(P=0.11)$ to be lower in L cows (Figure 2$)$, indicating an increase in size of individual alveoli. Fully differentiated cells were rarely observed in NL cows (Figure 1).

The DNA content of mammary parenchyma per milligram of wet weight was decreased $14 \%$ during lactation but total parenchymal DNA content tended to be greater (Table 2). The cellular content of RNA in mammary parenchyma of L cows, reflected in the RNA:DNA ratio, was twice that of NL cows. Similarly, the protein content of cells in the mammary parenchyma of $\mathrm{L}$ cows, reflected in the protein:DNA ratio, was approximately $30 \%$ greater than in NL cows.

Abundance of eIF2 $\alpha$ was significantly greater in the mammary parenchyma of L compared with NL cows but the proportion of eIF2 $\alpha$ in the phosphorylated form remained unchanged by physiological state at $11 \%$ (Table 3). Abundances of eIF4E and the 4EBP1 eIF4E complex were significantly greater in lactating mammary parenchyma, whereas phosphorylated eIF4E and the eIF4G-eIF4E complex tended to be greater, relative to $\mathrm{NL}$. The percentages of eIF4E in the free form or bound to eIF4G were not significantly different between groups, but the percentage of eIF4E in the 4EB$\mathrm{P} 1 \cdot \mathrm{eIF} 4 \mathrm{E}$ complex was greater in $\mathrm{L}$ than in NL mammary parenchyma (Figure 3 ).

\section{Comparison Between Mammary Parenchyma and Other Tissues}

Muscle exhibited significantly lower levels of RNA and DNA than either the mammary gland or liver (Figure 4). Whereas physiological state affected RNA and DNA levels in the mammary tissue, there was no effect in muscle and liver (Figure 4). The RNA levels in the lactating mammary parenchyma were 1.3 and 12.5 times greater than the averages in liver and muscle, respectively.

Total eIF2 $\alpha$ abundance in the lactating mammary gland was $1.9,1.5$, and 4.5 times greater than the average abundance in the NL mammary parenchyma, liver, and muscle, respectively (Figure 4). The proportion of eIF2 $\alpha$ in the phosphorylated form was not different between tissues. Phosphorylated rpS6 in lactating mammary parenchyma was expressed at the same abundance as in the liver, and 2.5 and 3.2 times greater than in the NL mammary parenchyma and muscle, respectively (Figure 4).

\section{DISCUSSION}

\section{Morphological Differences Between L and NL Udders}

To examine the involvement of translation initiation factors in the elevated protein synthetic capacity of the mammary gland during lactation, we compared multiparous, lactating cows with a cohort that had not been milked for $42 \mathrm{~d}$. We studied differences at the end of a normal lactation cycle and in the absence of the confounding mammogenic and lactogenic effects of pregnancy. The $83 \%$ increase in parenchymal DNA, or cell number, accounts for more than half of the $132 \%$ increase in parenchymal mass, although cell size was also increased in L cows as evidenced by the elevated protein:DNA ratio (Table 2) and alveolar size (Figure 
A

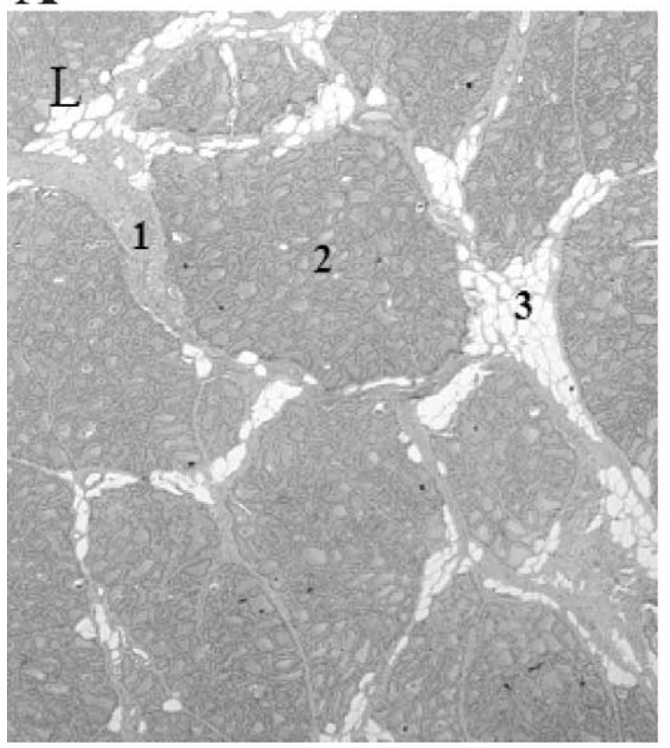

B

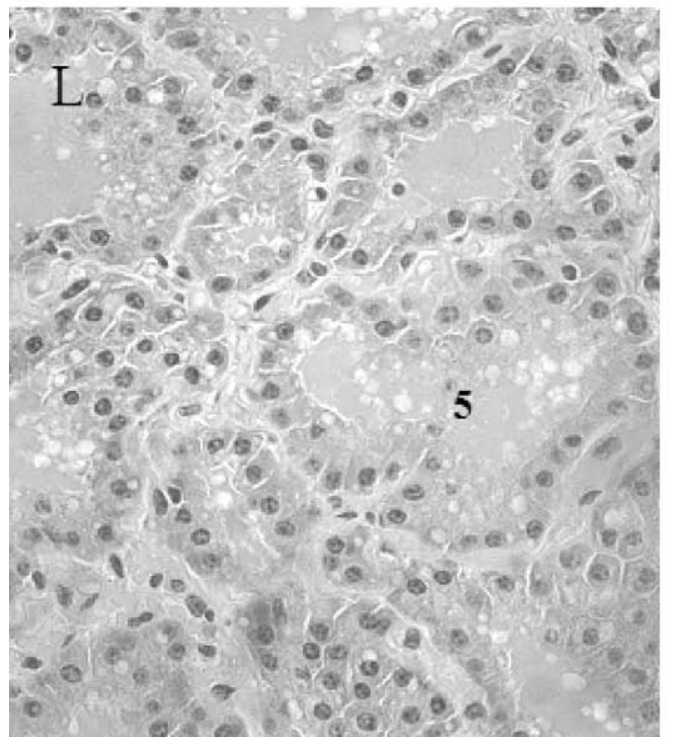

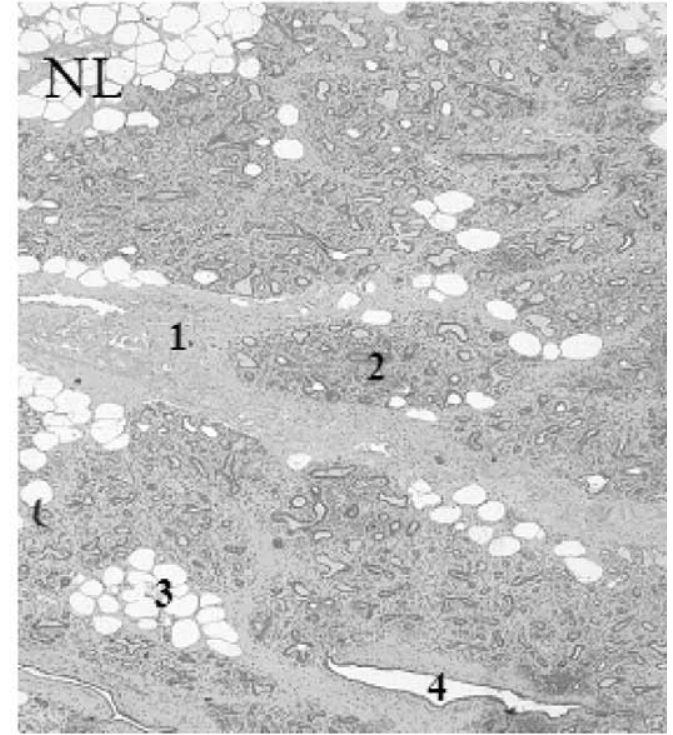

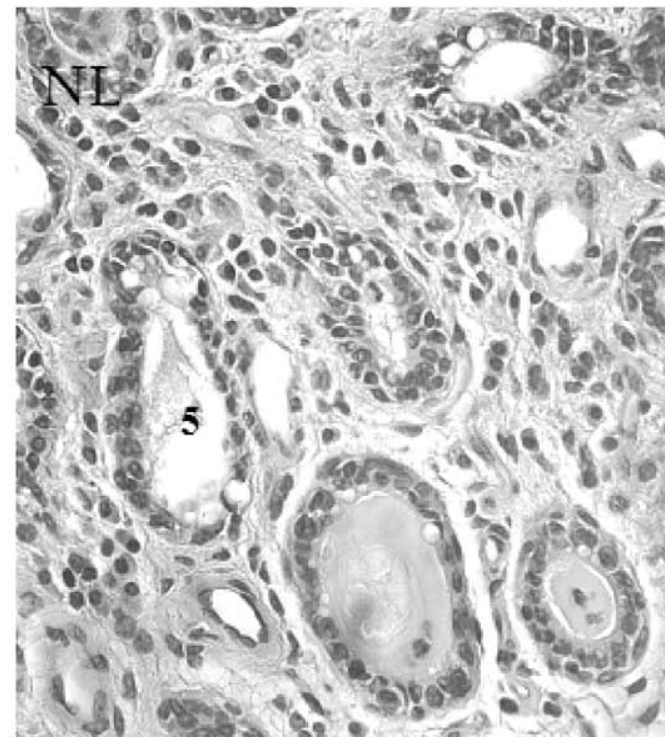

Figure 1. Representative micrographs of A) parenchyma (25×) and B) alveolar fractions (400x) in mammary tissue of nonpregnant lactating (L) and nonlactating (NL) cows: $1=$ connective tissue; $2=$ lobule; 3 = adipose tissue; $4=$ milk duct; and $5=$ alveolus.

2). Our observation that alveolar structure was largely preserved in the NL group (Figure 1) concurs with findings that the alveolar structure of ruminants appears to be partially maintained for several weeks even without a concurrent pregnancy (Tatarczuch et al., 1997). Cessation of milk removal from the mammary gland initiates a program of degradation of intracellular organelles necessary for milk production (Capuco and Akers, 1999), decreases in the ratio of cytoplasm to nucleus (Akers et al., 1990), loss in cell numbers through apoptosis (Wilde et al., 1997), and proteolytic degradation of the extracellular matrix (Quarrie et al., 1996) that would have resulted in the morphological differences observed between L and NL mammary parenchyma. The $83 \%$ difference in parenchymal DNA content observed in this study was less than the $181 \%$ difference reported for suckled compared with nonsuckled udder halves of beef cows after $42 \mathrm{~d}$ (Akers et al., 1990). The beef cows were slaughtered at 101 DIM, which is a much earlier stage of lactation than the cows 

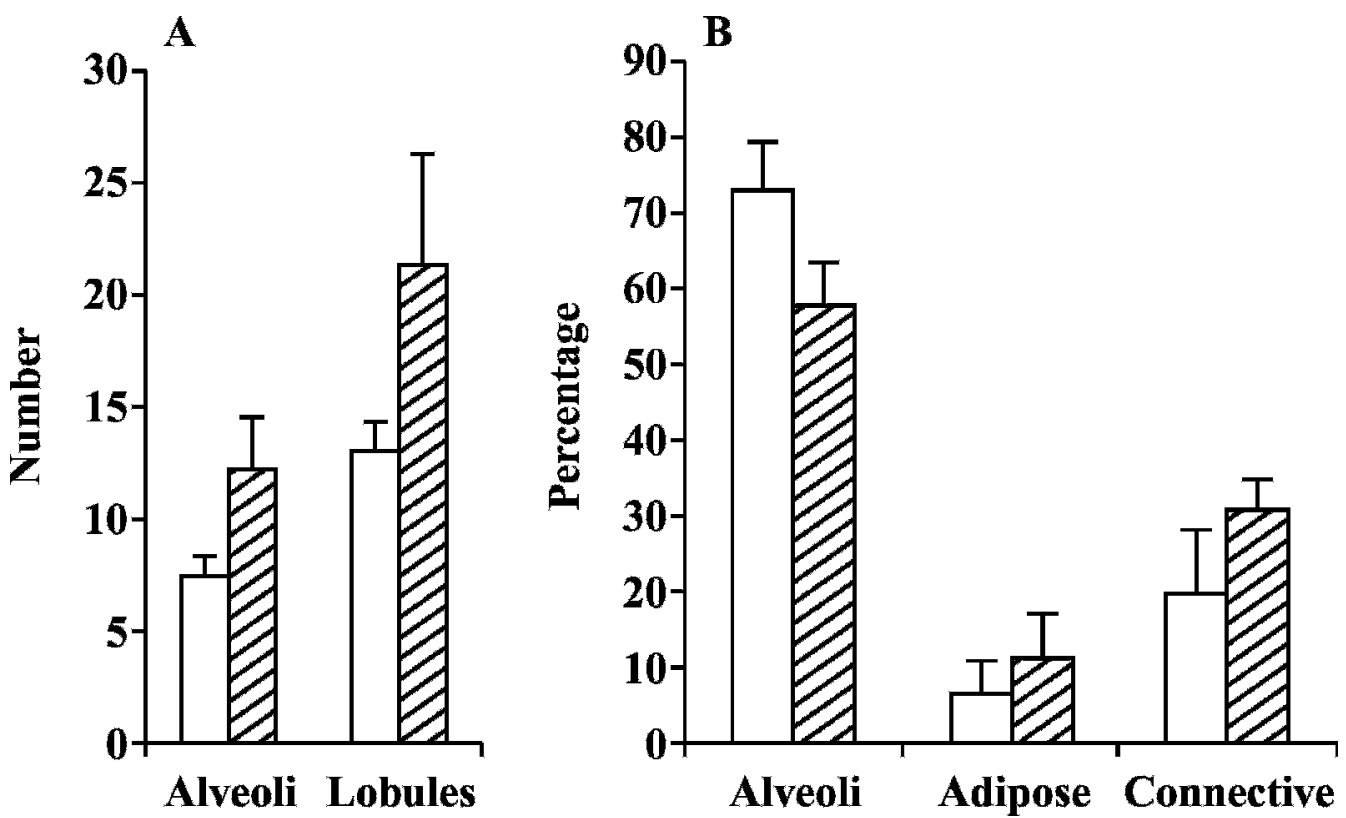

Figure 2. Comparison of A) the number of alveoli and lobules, and B) the percentage contribution of alveolar, adipose, and connective fractions, in the mammary parenchyma of nonpregnant lactating (white bars) and nonlactating (hatched bars) cows. Alveoli were counted intralobularly at $400 \times$ and lobules counted at $25 \times$ magnification. Data are means $\pm \mathrm{SE}$ for 4 animals/group.

in this study where larger effects of drying off might be expected.

Parenchymal protein synthetic capacity, indicated by RNA mass and the RNA:DNA ratio, was greater in $\mathrm{L}$ than in NL cows (Table 2). The RNA:DNA ratio of 1.6 is within the range of 1.3 to 1.8 reported for pregnant, lactating cows (Capuco et al., 1997). However, at 0.83, the mammary RNA:DNA in NL cows was only $65 \%$ of the average reported by Capuco et al. (1997) for dry but pregnant cows. During the dry period between successive lactations, the mammogenic and lactogenic stimulations of pregnancy oppose stimuli for mammary

Table 2. DNA, RNA, and protein content of mammary gland parenchyma of nonpregnant lactating $(\mathrm{L})$ and nonlactating $(\mathrm{NL})$ cows $(\mathrm{n}=$ 6/group)

\begin{tabular}{lcccl}
\hline & \multicolumn{2}{c}{ Group } & & \\
\cline { 2 - 3 } Item & $\mathrm{L}$ & $\mathrm{NL}$ & $\mathrm{SEM}$ & $P$-value \\
\hline Parenchymal content, g/kg & & & & \\
DNA & 2.52 & 2.88 & 0.09 & 0.014 \\
RNA & 4.17 & 2.38 & 0.24 & 0.0004 \\
Protein & 220.5 & 193.3 & 8.5 & 0.047 \\
Parenchymal ratio & & & & \\
$\quad$ RNA:DNA & 1.68 & 0.83 & 0.13 & 0.001 \\
Protein:DNA & 88.6 & 67.4 & 4.6 & 0.009 \\
Total parenchymal quantity, g & & & & \\
DNA & 26.2 & 14.3 & 4.4 & 0.09 \\
RNA & 41.4 & 11.6 & 4.0 & 0.003 \\
Protein & 2,308 & 984 & 362 & 0.027 \\
\hline
\end{tabular}

involution (Capuco and Akers, 1999) and sustain mammary integrity (Capuco et al., 1997).

\section{Abundance and Phosphorylation State of Translation Initiation Factors in Mammary Parenchyma}

The increases in parenchymal RNA content and mass in $L$ cows (Table 2 ) represent a scaling up of the transla-

Table 3. Relative expression per unit DNA of translation initiation factors (eIF) in mammary parenchyma of nonpregnant lactating (L) and nonlactating (NL) dairy cows

\begin{tabular}{lccc}
\hline & \multicolumn{2}{c}{ Group } & \\
\cline { 2 - 3 } Item & $\mathrm{L}$ & $\mathrm{NL}$ & $P$-value \\
\hline eIF2 & 6 & 6 & \\
$\mathrm{n}$ & $100 \pm 5$ & $39 \pm 3$ & 0.001 \\
Total eIF2 $\alpha$ & $100 \pm 12$ & $46 \pm 13$ & 0.22 \\
Phosphorylated eIF2 $\alpha$ & $11 \pm 0.8$ & $11 \pm 2.2$ & 0.99 \\
Percent phosphorylated & & & \\
eIF4E and its complexes & 3 & 3 & \\
$\mathrm{n}$ & $100 \pm 16$ & $56 \pm 8$ & 0.07 \\
eIF4E(P) & $100 \pm 22$ & $33 \pm 3$ & 0.04 \\
Total eIF4E & $100 \pm 30$ & $46 \pm 12$ & 0.17 \\
Unbound eIF4E & $100 \pm 46$ & $27 \pm 3$ & 0.02 \\
4EBP1·eIF4E & $100 \pm 29$ & $39 \pm 5$ & 0.11 \\
eIF4G·eIF4E & 6 & & \\
S6 and its kinase & $100 \pm 8$ & $32 \pm 10$ & 0.046 \\
$\mathrm{n}$ & $100 \pm 12$ & $56 \pm 11$ & 0.18 \\
rpS6(P) & & & \\
S6K1(P) & &
\end{tabular}




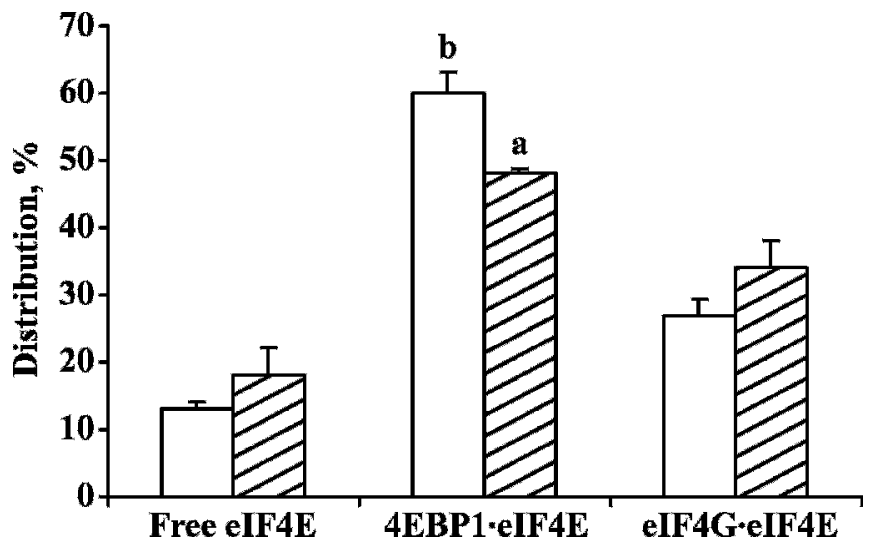

Figure 3. Distribution of eIF4E between free and complexed (4EBP1 and eIF4G) forms in mammary parenchyma of nonpregnant lactating (white bars) and nonlactating (hatched bars) cows. Data are means $\pm \mathrm{SE}$ for 3 animals/group. For each variable, values not sharing the same letter are significantly different, $P \leq 0.05$.

tional machinery needed for milk protein synthesis. Assuming a fractional synthesis rate of parenchymal protein in NL udders of $29 \% / \mathrm{d}$, as reported for nonlactating goats (Baracos et al., 1991), parenchymal protein synthesis was approximately $285 \mathrm{~g} / \mathrm{d}$, whereas the same fractional rate applied to the $\mathrm{L}$ parenchymal protein mass, plus $16.1 \mathrm{~kg} / \mathrm{d}$ milk at $3.3 \%$ protein, yields an estimate of $1,201 \mathrm{~g} / \mathrm{d}$. Thus, a conservative estimate, ignoring possible degradation of newly synthesized milk proteins, is a 4-fold increase in mRNA translation rate in L compared with NL tissue.

In eukaryotic cells, mRNA translation is controlled mainly at the point of initiation (Hershey, 1991) primarily through effects on eIF2, which is active in the formation of the 43S preinitiation complex (Proud, 2005), and eIF4E, which is crucial for the formation of the eIF4F trimer and its binding to the $5^{\prime}$ mRNA cap (Raught et al., 2001). Synthesis of translational components is regulated through the $\mathrm{S} 6$ kinases that phosphorylate rpS6 (Raught et al., 2001).

Eukaryotic initiation factor 2 consists of $\alpha, \beta$, and $\gamma$ subunits. Phosphorylation of the $\alpha$ subunit converts eIF2 from an exchange substrate to a competitive inhibitor of eIF2B, the eIF2 guanidine nucleotide exchange factor (Proud, 2005). Without exchange of guanosine diphosphate for guanosine triphosphate, eIF2 is unable to bind Met-transfer RNA and the 40S ribosomal subunit to form the $43 \mathrm{~S}$ preinitiation complex. Previous studies have established that the expression of the $\alpha$ subunit is representative of expression of the eIF2 holoenzyme (Voisin et al., 1996). Expression of eIF2 $\alpha$ per unit of DNA in L cows was 2.6-fold greater than in NL cows (Table 3 ) with no change in phosphorylation state. The lactation-related increase in cellular eIF2 $\alpha$ level
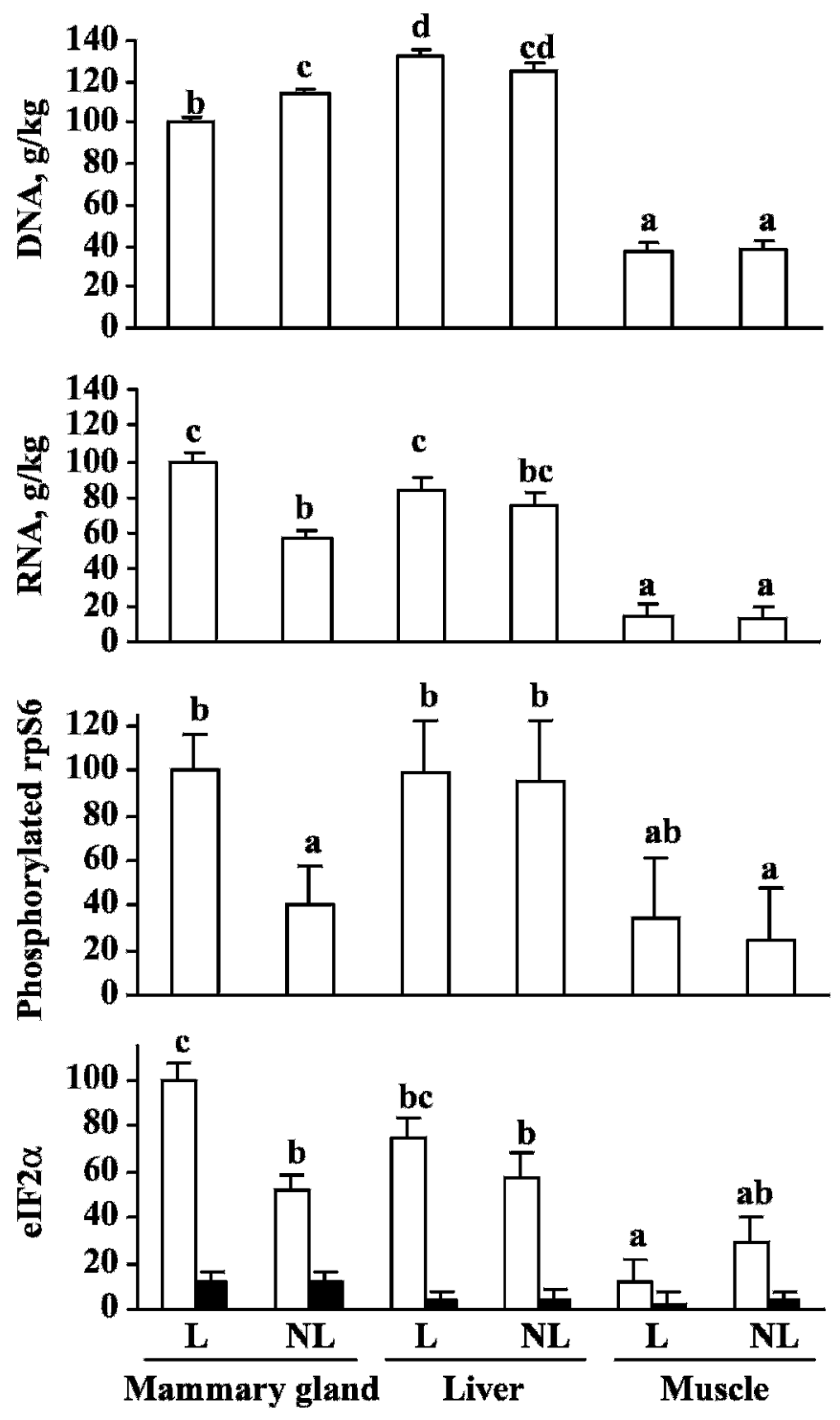

Figure 4. Least squares means of DNA (g/kg), RNA (g/kg), phosphorylated rpS6, and total eIF2 $\alpha$ (white bars) content (DNA unit basis), and percentage phosphorylated eIF2 $\alpha$ (black bars) of mammary parenchyma ( $n=6 /$ group), liver ( $n=3 /$ group), and muscle $(n=$ 3/group) of nonpregnant lactating (L) and nonlactating (NL) cows. Observations are expressed as a percentage of the value for the mammary gland of $\mathrm{L}$ cows. For each variable, values not sharing the same letter are significantly different, $P<0.05$.

was greater than the $102 \%$ increase in RNA:DNA ratio, indicating an elevated translational efficiency.

Eukaryotic initiation factor $4 \mathrm{~F}$ is a trimer of proteins consisting of eIF4E, eIF4A, and eIF4G, which disaggregates once the elongation step of mRNA translation commences. Formation of eIF4F is considered a ratedetermining step for translation under most circumstances and a primary target for translational control (Raught et al., 2001). One control point involves the 
binding protein $4 \mathrm{EBP} 1$ that sequesters eIF4E so that eIF4E cannot associate with eIF4G to form active eIF4F (Raught et al., 2001). A second control point is phosphorylation of eIF4E, which enhances its affinity for the mRNA cap several-fold (Minich et al., 1994). Similar to expression of eIF2 $\alpha$, total abundance of eIF4E per unit of DNA was 3 -fold greater in L than in NL cows (Table 3). The mechanisms responsible for the up-regulation of eIF4E level in response to growth factors are not completely understood, but a significant part of the increase is thought to be due to transcriptional activation (Raught et al., 2001). Lactational signals may similarly act at the transcriptional level to promote expression of these 2 initiation factors; eIF4E mRNA was elevated 8-fold in lactating mammary tissue compared with mammary tissue from virgin, postpubertal heifers (Long et al., 2001).

Phosphorylated, and therefore more active, eIF4E also tended to be greater in L cows than in NL cows. Phosphorylation at $\mathrm{Ser}^{209}$ in other tissues is mediated by downstream targets of protein kinase C (Proud, 2002), which is a known transducer of mitogenic influences on mammary development (Birkenfeld et al., 1996). Although L cows expressed considerably more eIF4E than NL cows, a greater proportion of it was sequestered in the $4 \mathrm{EBP} 1 \cdot \mathrm{eIF} 4 \mathrm{E}$ complex that renders eIF4E unavailable (Figure 3). This result is opposite to what is expected from the finding in vitro that lactogenic hormones stimulated phosphorylation of mammary 4EBP1 (Choi et al., 2004), which eliminates its ability to bind eIF4E (Raught et al., 2001). Given the high percentage of $4 \mathrm{EBP} 1 \cdot \mathrm{eIF} 4 \mathrm{E}$, it was evident mRNA translation was not operating at maximum capacity in either the L or NL group.

Phosphorylation of rpS6 is linked to an increase in the translation of mRNA containing oligopyrimidine motifs in untranslated regions adjacent to the cap structure (Jefferies et al., 1997). These mRNA code for parts of the translational machinery including ribosomal proteins, eEF1A and eEF2, and poly(A)-binding proteins (Raught et al., 2001). Ribosomal protein S6 is located near the mRNA/transfer RNA binding site on the $40 \mathrm{~S}$ ribosomal subunit, and is postulated to be optimally positioned for a role in selecting mRNA to be translated (Kimball, 2002). The mitogen-induced stimulation of S6K1, the rpS6 kinase, is also mediated by phosphorylation (Raught et al., 2001). Mutation of the phosphorylation site at $\mathrm{Thr}^{389}$ of $\mathrm{S} 6 \mathrm{~K} 1$ abolished the effect of rapamycin on eEF1A translation (Jefferies et al., 1997). The 3.1- and 1.8-fold greater levels of phosphorylated rpS6 and phosphorylated S6K1, respectively, in L vs. NL cows (Table 3) are indicative of an ability to sustain greater rates of synthesis of translational machinery, which is also evident in the 2-fold difference in mammary RNA:DNA between the 2 groups.

Although fractional rates of protein synthesis in liver and muscle did not appear to be different between $\mathrm{L}$ and NL goats (Baracos et al., 1991), we chose to measure abundances of the rpS6 and eIF2 in these 2 tissues of $\mathrm{L}$ and NL cows to compare with mammary abundances in the same animals. To our knowledge, these 2 regulators of global protein synthesis have not been measured in bovine liver and muscle before, although their activation in liver and muscle of rodents and swine following consumption of a meal is quite well characterized (Yoshizawa et al., 1997; Davis et al., 2000; Kimball et al., 2000). Mammary activity of eEF2 was 20 times greater than liver activity in lactating cows (Christophersen et al., 2002). We did not observe such radical differences between the organs; abundance of phosphorylated rpS6 was not different and eIF2 $\alpha$ was only $50 \%$ greater in mammary tissue (Figure 4). In semimembranosus muscle, where protein turnover may be 10 times slower than in liver or the mammary glands (Baracos et al., 1991), abundances of phosphorylated rpS6 and eIF2 $\alpha$ were 3 to 4 times lower than in mammary parenchyma (Figure 4).

\section{Role of Translation Initiation in Control of Milk Protein Synthesis}

The observations of abundance and phosphorylation state of initiation factors in mammary parenchyma allow us to make 2 inferences. First, the increased abundances of eIF $2 \alpha$, eIF4E, and phosphorylated $\operatorname{rpS} 6$ in L tissue that is synthesizing protein at least 4 times faster than NL tissue suggest that up-regulation of translation initiation may be a necessary prerequisite, and therefore an important control point, for milk protein synthesis in the fully differentiated milk secretory cell. Second, the proportions of eIF $2 \alpha$ in the inhibitory, phosphorylated form and eIF4E in the sequestered, unavailable form indicate that translation initiation was not operating at a maximum rate and might be elastic to external stimuli. The identity of these stimuli in mammary tissue remains relatively unknown, although amino acid deprivation has recently been shown to increase the association of $4 \mathrm{EBP} 1$ for eIF4E in bovine mammary epithelial cells in culture (Moshel et al., 2006), as it does in liver and muscle tissue (Davis et al., 2000; Kimball et al., 2000). Elements of translational control of milk protein synthesis via nutrient signaling may help to explain the low and variable responses of milk protein yield to nutritional perturbations (Hanigan et al., 1998). 


\section{ACKNOWLEDGMENTS}

The authors wish to thank Scott Cieslar, Cathy Cullingham, Jen Ellis, Reza Imamidoost, Fulong Qiao, Candace Stewart, Tammi Weekes, Changting Xiao, and Melissa Yau for their help in sample collection and analysis. The assistance of staff at the Elora Dairy Research Centre and the Meat Laboratory is gratefully acknowledged. Financial support for this work was provided by NSERC Canada and the Ontario Ministry of Agriculture and Food.

\section{REFERENCES}

Akers, R. M., W. E. Beal, T. B. McFadden, and A. V. Capuco. 1990. Morphometric analysis of involuting bovine mammary tissue after 21 or 42 days on non-suckling. J. Anim. Sci. 68:3604-3613.

Anthony, T. G., J. C. Anthony, F. Yoshizawa, S. R. Kimball, and L. S. Jefferson. 2001. Oral administration of leucine stimulates ribosomal protein mRNA translation but not global rates of protein synthesis in the liver of rats. J. Nutr. 131:1171-1176.

Baracos, V. E., J. Brun-Bellut, and M. Marie. 1991. Tissue protein synthesis in lactating and dry goats. Br. J. Nutr. 66:451-465.

Bigot, K., M. Taouis, and S. Tesseraud. 2003. Refeeding and insulin regulate $\mathrm{S} 6 \mathrm{~K} 1$ activity in chicken skeletal muscles. J. Nutr. 133:369-373.

Birkenfeld, H. P., B. S. McIntyre, and K. P. Briski. K. P., and P.W. Sylvester. 1996. Protein kinase C isoenzyme expression in normal mouse mammary epithelial cells grown in primary culture. Proc. Soc. Exp. Biol. Med. 213:65-70.

Capuco, A. V., and R. M. Akers. 1999. Mammary involution in dairy animals. J. Mammary Gland Biol. Neoplasia 4:137-144.

Capuco, A. V., R. M. Akers, and J. J. Smith. 1997. Mammary growth in Holstein cows during the dry period: Quantification of nucleic acids and histology. J. Dairy Sci. 80:477-487.

Choi, K. M., I. Barash, and R. E. Rhoads. 2004. Insulin and prolactin synergistically stimulate $\beta$-casein messenger ribonucleic acid translation by cytoplasmic polyadenylation. Mol. Endocrinol. 18:1670-1686.

Christophersen, C. T., J. Karlsen, M. O. Nielsen, and B. Riis. 2002. Eukaryotic elongation factor-2 (eEF-2) activity in bovine mammary tissue in relation to milk protein synthesis. J. Dairy Res. 69:205-212.

Davis, T. A., H. V. Nguyen, A. Suryawan, J. A. Bush, L. S. Jefferson, and S. R. Kimball. 2000. Developmental changes in the feedinginduced stimulation of translation initiation in muscle of neonatal pigs. Am. J. Physiol. 279:E1226-E1234.

Evans, P. C., F. M. Ffolliott-Powell, and J. E. Harding. 1993. A colorimetric assay for amino nitrogen in small volumes of blood: Reaction with $\beta$-naphthoquinone sulfonate. Anal. Biochem. 208:334-337.

Hanigan, M. D., J. P. Cant, D. C. Weakley, and J. L. Beckett. 1998. An evaluation of postabsorptive protein and amino acid metabolism in the lactating dairy cow. J. Dairy Sci. 81:3385-3401.

Hershey, J. W. B. 1991. Translational control in mammalian cells. Annu. Rev. Biochem. 60:717-755.

Jefferies, H. B. J., S. Fumagalli, P. B. Dennis, C. Reinhard, R. B. Pearson, and G. Thomas. 1997. Rapamycin suppresses 5'TOP mRNA translation through inhibition of p70-s6k. EMBO J. 16:3693-3704.

Kimball, S. R. 2002. Regulation of global and specific mRNA translation by amino acids. J. Nutr. 132:883-886.

Kimball, S. R., D. A. Antonetti, R. M. Brawley, and L. S. Jefferson. 1991. Mechanism of inhibition of peptide chain initiation by amino acid deprivation in perfused rat liver. Regulation involving inhibition of eukaryotic initiation factor 2alpha phosphatase activity. J. Biol. Chem. 266:1969-1976.

Kimball, S. R., and L. S. Jefferson. 1992. Regulation of protein synthesis by modulation of intracellular calcium in rat liver. Am. J. Physiol. 263:E958-E964.

Kimball, S. R., L. S. Jefferson, H. V. Nguyen, A. Suryawan, J. A. Bush, and T. A. Davis. 2000. Feeding stimulates protein synthesis in muscle and liver of neonatal pigs through an mTOR-dependent process. Am. J. Physiol. 279:E1080-E1087.

Kimball, S. R., J. P. O'Malley, J. C. Anthony, S. J. Crozier, and L. J. Jefferson. 2004. Assessment of biomarkers of protein anabolism in skeletal muscle during the life span of the rat: Sarcopenia despite elevated protein synthesis. Am. J. Physiol. 287:E772E780.

Lendrum, A. C., D. S. Fraser, W. Slidders, and R. Henderson. 1962. Studies on the character and staining of fibrin. J. Clin. Pathol. 15:401-413.

Long, E., A. V. Capuco, and X. Zhao. 2001. Cloning of bovine eukaryotic translation initiation factor $4 \mathrm{E}$ (eIF-4E) and its expression in the bovine mammary gland at different physiological stages. DNA Seq. 12:319-329.

Minich, W., D. Gross, and R. Rhoads. 1994. Chromatographic resolution of in vivo phosphorylated and nonphosphorylated eukaryotic initiation factor eIF-4E: Increased cap affinity of the phosphorylated form. Proc. Natl. Acad. Sci. USA 91:7668-7672.

Moshel, Y., R. E. Rhoads, and I. Barash. 2006. Role of amino acids in translational mechanisms governing milk protein synthesis in murine and ruminant mammary epithelial cells. J. Cell. Biochem. 98:685-700.

Nobukuni, T., M. Joaquin, M. Roccio, S. G. Dann, S. Y. Kim, P. Gulati, M. P. Byfield, J. M. Backer, F. Natt, J. L. Bos, F. J. Zwartkruis, and G. Thomas. 2005. Amino acids mediate mTOR/raptor signaling through activation of class 3 phosphatidylinositol $30 \mathrm{H}$-kinase. Proc. Natl. Acad. Sci. USA 102:14238-14243.

Prophet, E. B., B. Mills, J. B. Arrington, and L. H. Sobin. 1992. Laboratory Methods in Histotechnology. Armed Forces Institute of Pathology, American Registry of Pathology, Washington, DC.

Proud, C. G. 2002. Regulation of mammalian translation factors by nutrients. Eur. J. Biochem. 269:5338-5349.

Proud, C. G. 2005. eIF2 and the control of cell physiology. Semin. Cell Dev. Biol. 16:3-12.

Quarrie, L. H., C. V. P. Addey, and C. J. Wilde. 1996. Programmed cell death during mammary tissue involution induced by weaning, litter removal, and milk stasis. J. Cell. Physiol. 168:559-569.

Raught, B., A.-C. Gingras, and N. Sonenberg. 2001. The target of rapamycin (TOR) proteins. Proc. Natl. Acad. Sci. USA 98:7037-7044.

Rosen, J. M., S. L. Wyszomierski, and D. Hadsell. 1999. Regulation of milk protein gene expression. Annu. Rev. Nutr. 19:407-436.

SAS Institute. 2000. SAS/STAT User's Guide. Version 8. SAS Institute, Inc., Cary, NC.

Tatarczuch, L., C. Philip, and C. S. Lee. 1997. Involution of the sheep mammary gland. J. Anat. 190:405-416.

Vary, T. C., G. Deiter, and S. A. Goodman. 2005. Acute alcohol intoxication enhances myocardial eIF4G phosphorylation despite reducing mTOR signaling. Am. J. Physiol. 288:H121-H128.

Voisin, L., K. Gray, K. M. Flowers, S. R. Kimball, L. S. Jefferson, and T. C. Vary. 1996. Altered expression of eukaryotic initiation factor $2 \mathrm{~B}$ in skeletal muscle during sepsis. Am. J. Physiol. 270:E43-E50.

Wilde, C. J., C. V. P. Addey, and D. G. Fernig. 1997. Programmed cell death in bovine mammary tissue during lactation and involution. Exp. Physiol. 82:943-953.

Yoshizawa, F., S.R. Kimball, and L.S. Jefferson. 1997. Modulation of translation initiation in rat skeletal muscle and liver in response to food intake. Biochem. Biophys. Res. Commun. 240:825-831. 